\title{
Mikrobiyal Gübre Uygulamasının Tatlı Mısır (Zea mays L. var. saccharata) Yetiştiriciliğinde Bitki Gelişimi ve Verim Üzerine Etkileri
}

\author{
Hakan ALTUNLU ${ }^{1 *}$ Okay DEMIRAL ${ }^{2}$ (D) Oktay DURSUN ${ }^{3}$ \\ Mustafa SÖNMEZ ${ }^{3}$ Kubilay ERGÜN ${ }^{3}$ iD \\ ${ }^{1}$ Muğla Sitkı Koçman Üniversitesi, Ortaca Meslek Yüksekokulu, Muğla, Türkiye \\ ${ }^{2}$ Koppert Biyolojik Mücadele ve Polinasyon Sistemleri Sanayi ve Tic. Ltd. Şti., Antalya, Türkiye \\ ${ }^{3}$ Muğla Sitkı Koçman Üniversitesi, Fen Fakültesi, Biyoloji Bölümü, Muğla, Türkiye \\ (*Sorumlu yazar e-mail: haltunlu@gmail.com) \\ DOI: 10.17097/ataunizfd.424032 \\ Geliş Tarihi (Received Date): 16.05.2018 \\ Kabul Tarihi (Accepted Date): 04.11.2018
}

\begin{abstract}
ÖZ: Bitki büyüme ve gelişmesi için gerekli olan besin maddelerini sağlayan inorganik kimyasal gübreler verimi artırırlar ancak bu kimyasalların, bilinçsiz ve aşırı kullanımı insan ve çevre sağlığı açısından olumsuz sonuçlara neden olur. Günümüzde çevre dostu tarım yaklaşımlarından bazıları, bitkilerin besin maddesi alınımını, gelişimini, biyotik ve abiyotik stres koşullarına dayanımını arttıran kök bölgesinde serbest veya simbiyoz yaşayan bakterileri, ekto ve endomikorizaları ve daha birçok faydalı mikroorganizmayı kapsar. Bu araştırma, Endomycorrhiza, Trichoderma spp., Bacillus subtilis ve Bacillus megaterium içeren bir ticari mikrobiyal gübrenin dört farklı doz $\left(0,2,4,8 \mathrm{ml} \mathrm{kg}{ }^{-1}\right.$ tohum) uygulamasının tatlı mısır (Zea mays L. var. saccharata) yetiștiriciliğinde bitki gelişimi ve verim üzerine etkilerini belirlemek amaciyla yürütülmüștür. Tohum çimlenme yüzdesi, bitki boyu, bitki çapı, bitki başına koçan sayısı, ortalama kavuzlu ve kavuzsuz koçan ağırlığı, koçan verimi, koçan boyu, koçan çapı, koçanda sıra sayısı, sırada dane sayısı, toplam suda çözünür kuru madde (TSÇKM) değerleri belirlenmiştir. Elde edilen sonuçlar, mikrobiyal gübre uygulaması dozlarının artıșı ile bitki gelișimi, kavuzlu ve kavuzsuz koçan ağırlığı ve veriminin artığını göstermiştir. Ölçülen birçok parametrede 4 ve $8 \mathrm{ml} \mathrm{kg}^{-1}$ tohum dozlarının yakın sonuçlar vermiştir ve daha az kullanım bakımından $4 \mathrm{ml} \mathrm{kg}^{-1}$ tohum dozunun uygun doz olarak önerilebileceği sonucuna varılmıştır.
\end{abstract}

Anahtar Kelimeler: Tatlı mısır, Verim, Mikrobiyal Gübre, PGPR

\section{Effects of Microbial Fertilizer Application on Growth and Yield of Sweet Corn (Zea mays L. var. saccharata)}

\begin{abstract}
Inorganic chemical fertilizers provided essential elements in plant growth and development increases yield and quality of plants, but their unconscious and extreme usage may cause a serious threat to human health and environment. Today some eco-friendly agricultural approaches includes free or symbiotic bacteria, endo- and ectomycorrhizal fungi and many other useful microscopic organisms in the root zone led to improve nutrient uptake, plant growth and plant tolerance to abiotic and biotic stress. This research was conducted in order to investigate effects of four different dose applications $\left(0,2,4,8 \mathrm{ml} \mathrm{kg}{ }^{-1} \mathrm{seed}\right)$ of commercial microbial fertilizer containing Endomycorrhiza, Trichoderma spp, Bacillus subtilis and Bacillus megaterium on growth and yield of sweet corn (Zea mays L. var. saccharata). The percentage of seed emergence, plant height, plant diameter, ear number per plant, average ear weight with and without husked, ear yield, ear length, ear diameter, number of kernels per row, number of kernels on row and total soluble solid (TSÇKM) were determined. The results showed that plant growth, ear weight with and without husked and yield were increased by application of increasing doses of microbial fertilizer. $4 \mathrm{ml} \mathrm{kg}{ }^{-1} \mathrm{seed}$ and 8 $\mathrm{ml} \mathrm{kg}{ }^{-1}$ seed doses gave close results in many measured parameters and because of less and economic usage, $4 \mathrm{ml} / \mathrm{kg}$ seed dose were determined as advising dose.
\end{abstract}

Keywords: Sweet corn, Yield, Microbial fertilizer, PGPR

\section{GíRiş}

Ülkemizde taze, dondurulmuş ve konserve sanayinde değerlendirilen şeker ve yağ oranı bakımından zengin tatlı misırın (Zea mays L. var saccharata) üretimi ve tüketimi gittikçe artmaktadır. Dünyada tatlı mısır üretimi 9.182.177 ton olup, Amerika Birleşik Devletleri ve Meksika en fazla üretim yapan ülkelerdir (Anonim, 2016). Ülkemizde tatlı mısır ekim alanları ve üretim miktarları ile ilgili yeterli istatistiki çalışma yoktur. Taze tüketimde kullanılan at dişi ve sert mısıra göre tatlı mısırın sağladığ1 tat avantaj1 ve yeme üstünlüğü üretimini giderek artırmaktadır (Turgut, 2000).

Biyolojik mücadelede kullanılan bazı mikroorganizmaların bitkinin gelişimini de teşvik edebildiği birçok çalışmada bildirilmiştir (Küçük ve Güler, 2009). Günümüzde sürdürülebilir bir tarım için, biyolojik gübreler ile toprak rizosferinin güçlendirilmesini, simbiyotik yaşamla daha fazla bitki besin elementi alınımını ve kimyasal gübrelemenin azaltılmasını amaçlayan araştırmalar ivme kazanmıştır (Çakmakçı, 2005). Bitki büyümesini teşvik eden rizobakteriler (PGPR) ve bitki büyümesini teşvik eden mantarlar (PGPF) ile ilgili çalışmalarda, bunların bitki büyümesini teşvik mekanizmaları; kökleri patojen saldırılarından korumaları, içsel etilen miktarını düşürmeleri, daha fazla besin maddesi alınımını sağlamaları ve bitki gelişim hormonu gibi davranan metabolitler üretmeleri olarak gösterilmiştir (Whipps, 2001; Antoun and Prevost, 2005; El-Katatny and Idres, 2014). 
Her türlü toprakta geniş yayılım gösterebilen saprofitik karakterli Trichoderma türleri bitki kök hastalıklarına karşı kullanılan yaygın bir biyolojik mücadele ajanıdır. Trichoderma hiperparatizim, antibiozis ve rekabet gibi biyolojik savaş mekanizmaları ile bitki hastalıklarını baskılarken (Bora vd., 1995), Trichoderma'nın ürettiği sekonder metabolitler bitkide oksin benzeri bileşikler olarak görev yaparlar (Kleifeld ve Chet, 1992; Benitez et al., 2004; Vinale et al., 2008). Trichoderma uygulamaları kök bölgesini asitleştirir ve kök büyümesini teşvik eder ve bu da üst aksamın gelişimini olumlu etkiler, verimi önemli derecede artırır (Vinale et al., 2008). Harman (2000), azotça fakir topraklarda misır yetiştiriciliğinde $T$. harzianum (T-22) uygulamasının, gelişim dönemi başında daha boylu ve yeşil bitkiler oluşturduğunu, hasat döneminde dane ve slaj veriminin kontrole göre daha yüksek olduğunu bildirmiştir.

Mikoriza, bazı bitki türleri ile karşılıklı bir yaşam biçimi geliştirmiş olan mantarları tanımlanmaktadır (Smith and Read, 2008). Mikorizalar ekto ve endo mikoriza olarak iki ana gruba ayrılırlar. Endo mikorizalar kök kortekstinde hem hücreler arası boşlukta hem de hücre içinde yayılırlar (Smith and Read, 1997). Endomikorizaların hücre içerisinde oluşturdukları, besin elementlerini bitki dokularına aktaran yapıları arbüskül olarak adlandırılmakta, arbüskül oluşturan mikorizalar arbüsküler mikoriza mantarları (AMF) olarak isimlendirilmektedir (Ortaş vd., 1999). Arbüsküler mikorizanın bitki kök yüzeyini artırarak bitkiye mineral besinleri özellikle de fosfor $(\mathrm{P})$ ve çinkoyu (Zn) sağladığı, su alınımını artırdığı, azot ve karbon döngüsünü olumlu yönde etkilediği, biyotik ve abiyotik stres koşullarına dayanımı artırdığı birçok çalışmada ortaya konmuştur (Ortaş, 2000; Smith and Read, 2008; Küçük ve Güler, 2009).

Bitki gelişimini teşvik eden bakteriler (Plant Growth Promoting Rhizobacteria=PGPR) Azotobacterium, Azospirillum, Azotobacter,
Alcaligenes, Bacillus, Bradyrhizobium, Burkholderia, Clostridium, Enterobacter, Flavobacterium, Klebsiella, Pseudomonas ve Rhizobium gibi cinslere ait bazı türlerden oluşur ve kök bölgesinde yaşayan tüm bakterilerin sadece \%1-2'sini oluşturlar (Antoun and Kloepper, 2001; Adesemoye et al., 2008). PGPR'lerin havadaki azotu bağlayarak, çözülemez formdaki fosforu serbest hale getirerek, su alınımını ve bitkisel fitohormon üretimini teşvik ederek bitki gelişimini ve verimini arttırdıkları belirlenmiştir (Glick 1995; Garcia et al., 2003; Misra et al., 2010). Ayrıca PGPR uygulamaları toprak kökenli patojenleri baskılar, kuraklık ve tuzluluk gibi abiyotik stress koşullarına dayanımı arttırır (Jeon et al., 2003; Güneş vd., 2013; Ram et al., 2013). Birçok bitki türünde Bacillus subtilis, Bacillus megaterium, Bacillus amyloliquefaciens ve Bacillus spp gibi Bacillus ırkları ile yapılan çalışmalarda, bakterilerin salgıladıkları organik asitler (oksalik, laktik ve sitrik asit) ve alkalin fosfotaz enzimi ile toprakta bağlı fosforu çözerek bitkisel gelişme ve verimde artışlar sağladıkları saptanmıştır (Güneş vd., 2009; Güneş vd., 2013).

T. harzianum ile mikoriza arasındaki olumlu ilişki birçok farklı bitkide denenmiş ve ikisinin beraber kullanımlarında olumlu sonuçlar bildirilmiştir. (Vazguez et al., 2000; Meyer and Roberts, 2002; Srivastava et al., 2010; Raupach and Kloepper, 1998).

\section{MATERYAL VE METOT}

Araştırma 2017 yılında Antalya Elmalı Kışla köyünde toplam $4000 \mathrm{~m}^{2}$ alanda, Merit F1 tatlı mısır (Zea mays L. var. saccharata) çeşidi kullanılarak kurulmuştur. Araştırma toprağının bazı fiziksel ve kimyasal özellikleri Çizelge 1 'de verilmiştir. Toprağın organik madde içeriği $(\% 2.2)$ ve kireç içeriği orta seviyededir (\%5.50). Araştırma toprağının $\mathrm{pH}$ 'sı hafif alkali (7.8) olup tuzluluk problemi bulunmamaktadır.

Çizelge 1. Araştırma toprağına ait bazı fiziksel ve kimyasal özellikler.

\begin{tabular}{|c|c|c|}
\hline Bünye & $\begin{array}{l}\text { Kum (\%) } \\
\text { Silt (\%) } \\
\text { Mil (\%) } \\
\end{array}$ & Kumlu Killi Tın \\
\hline $\mathrm{pH}$ & & 7.8 \\
\hline $\mathrm{EC}(\mathrm{dS} / \mathrm{m})$ & & 0.27 \\
\hline Suyla Doygunluğu (\%) & & 53.10 \\
\hline Kireç Kapsamı (\%) & & 5.50 \\
\hline Organik Madde (\%) & & 2.2 \\
\hline Toplam N (\%) & & $0.08 \quad \mathrm{Az}$ \\
\hline Alınabilir $\mathrm{P}\left(\mathrm{P}_{2} \mathrm{O}_{5} \mathrm{~kg} / \mathrm{da}\right)$ & & $2.09 \mathrm{Az}$ \\
\hline Alınabilir $\mathrm{K}\left(\mathrm{K}_{2} \mathrm{O} \mathrm{kg} / \mathrm{da}\right)$ & & 30.10 Orta \\
\hline Alınabilir $\mathrm{Ca}(\mathrm{ppm})$ & & 3036 Yüksek \\
\hline Alınabilir Mg (ppm) & & 837 Yüksek \\
\hline Alınabilir Fe (ppm) & & 5.0 Yeterli \\
\hline Alınabilir Mn (ppm) & & 6.1 Düşük \\
\hline Alınabilir Zn (ppm) & & 1.8 Yeterli \\
\hline Alınabilir $\mathrm{Cu}$ (ppm) & & 1.2 Yeterli \\
\hline
\end{tabular}


Araştırmada içeriğinde Endomycorrhiza (>100 propagules/ml), Trichoderma $\mathrm{spp} .\left(>1 \times 10^{9} \mathrm{kob} \mathrm{ml}^{-1}\right)$, Bacillus subtilis $\left(1 \times 10^{8} \mathrm{kob} \mathrm{ml}^{-1}\right)$ ve Bacillus megaterium $\left(1 \times 10^{8} \mathrm{kob} \mathrm{ml}^{-1}\right)$ bulunan biyolojik gübre kullanılmıştır. Araştırma konularını biyolojik gübre (1) $2 \mathrm{ml} \mathrm{kg}^{-1}$ tohum; (2) $4 \mathrm{ml} \mathrm{kg}{ }^{-1}$ tohum; (3) $8 \mathrm{ml} \mathrm{kg}$ ${ }^{1}$ tohum uygulama dozları ile (4) gübresiz (Kontrol) $0 \mathrm{ml} \mathrm{kg}{ }^{-1}$ tohum dozu oluşturmuştur. Misır tohumları $\%$ 2'lik sodyum hipoklorit içinde 3 dakika bekletilerek, yüzeysel dezenfeksiyona tabi tutulmuş, steril saf sudan geçirildikten sonra, deneme konularına bağlı dozlar $100 \mathrm{ml}$ saf suya ilave edilmiş ve $1 \mathrm{~kg}$ tohum üzerine püskürtülerek karıştırılmış, steril kurutma kağıtları üzerinde gölgede kurumaya bırakılmıştır. Kontrol uygulamasında tohumların üzerine saf su uygulaması yapılmıştır. Her bir 250 $\mathrm{m}^{2}$ 'lik uygulama parseline tohumlar pnömatik tohum ekim mibzeri (4 sıralı) ile sıra aras $10 \mathrm{~cm}$ sıra üzeri $20 \mathrm{~cm}$ olacak şekilde $6 \mathrm{~km} \mathrm{~h}^{-1}$ ilerleme hızında, 7140 adet tohum dekar'-1 olacak şekilde $5 \mathrm{~cm}$ derinliğinde ekilmiştir. Ekimle birlikte $50 \mathrm{~kg} \mathrm{da}{ }^{-1}$ 15:15:15 $(\mathrm{N}: \mathrm{P}: \mathrm{K})$ taban gübresi verilmiştir. Uygulamaların tamamında aynı ekim makinası kullanılmış, uygulamalar arasında makine yıkanarak temizlenmiştir. Tohum ekimi 26.05.2016 tarihinde yapılmış olup, hasat işlemi 21.08.2016 tarihinde gerçekleştirilmiştir. Tohum ekiminden hasada kadar düzenli olarak kültürel uygulamalar yapılmış, bitkiler $15 \mathrm{~cm}$ boylandığında sulama karıkları açılarak çiçeklenme ve tane dolumu dönemlerinde birer kez olmak üzere salma sulama yapılmıştır.

Tohumun çimlenme yeteneğini belirlemek amacıyla ekimden sonra bitki çıkışları gözlenmiştir. Her parselde belirlenen $0,25 \mathrm{~m}^{2}$ blokta çimlenme periyodu gözlenmiş, çimlenmenin sabitlendiği zamana kadar filizler sayılmış çimlenme yüzdesi hesaplanmıştır (Erbach, 1982).

Bitkilerin koçan püsküllerinin kahverengiye döndüğü dönemde hasat işlemi yapılmıştır. Bitkilerin fiziksel özelliklerinin belirlenmesinde, her parselde rastgele seçilen 20 bitkinin hasat zamanında boyları metre ile ölçülerek bitki ortalama boyu $(\mathrm{cm})$, bitkinin yeşil aksamının alttan ikinci boğumunun ortasından çapları kumpast ile ölçülerek ortalama bitki çapı $(\mathrm{cm})$ belirlenmiştir. Bu yirmi bitkiden toplanan koçanların bitki sayısına bölünmesi ile bitki başına koçan adedi, taze koçanların koçan yapraklarıyla tartılıp koçan sayısına bölünmesiyle ortalama kavuzlu koçan ağırlığı (g) bulunmuştur. Aynı koçanlar kavuzları ayıklandıktan sonra tartılarak ortalama kavuzsuz koçan ağırlığı (g), koçanın tabanı ile tepe noktası arasındaki mesafe ölçülerek ortalama koçan boyu $(\mathrm{cm})$ ve koçanlar en geniş yerlerinden kumpas yardımıyla ölçülerek koçan çapı (mm) belirlenmiştir. Verim değeri parsellerdeki tüm koçanların kavuzları temizlendikten sonra tartılması ve dekara çevrilmesi ile saptanmıştır.
Koçandaki sıralar sayılarak sıra sayısı; koçanda her sırada dane sayıları sayılarak sıradaki dane sayısı, danelerin suyu sikılarak alınan $10 \mathrm{ml}$ örnek santrifüjde 10000 devirde 20 dakika bekletilerek toplam suda çözünür kuru madde miktarı (TSÇKM) saptanmıştır.

Hasat sonrası parsellerden rastgele seçilen 5 adet bitki bel küreği ile topraktan çıkarılarak mikorizal kolonizasyonu belirlemek amaciyla kök örnekleri alınmıştır. Örnek olarak alınan kökler yıkanmış ve olası bozulma-mikrobiyal gelişmeyiengellemek amaciyla AFA (Alkol: Formaldehit: Asetik Asit; V:V:V 90:5:5) çözeltisinde bekletilmiştir. Kolonizasyon Gridline Intersection Method (Giovanetti and Mosse, 1980) kullanılarak belirlenmiştir.

Tesadüf blokları deneme deseni düzeninde 4 tekrarlı olarak yürütülen araştırmadan elde edilen veriler, SPSS (sürüm 12.0) istatistik paket programinda deneme desenine uygun olarak değerlendirilmiştir. Ortalamalar arasındaki farklılıkları belirlemek için \% 5 önem düzeyinde LSD testi kullanılmıştır.

\section{BULGULAR VE TARTISMA}

Biyolojik gübre uygulamasının tatlı misır bitkisinin tohum çimlenmesi yüzdesi üzerine etkisi Çizelge 2'de verilmiştir. Biyolojik gübre uygulamasının tüm dozlarının kontrol uygulamasına göre çimlenme oranını \% 9.05 ila \% 13.03 oranında arttırdığı, ancak uygulama dozları arasında tohum çimlenmesi yüzdesi bakımından istatistiki olarak bir farklılık bulunmadığı saptanmıştır. Çalışmamızdaki bu sonuç önceki çalışmalar ile uyumludur. Björkman et al. (1998), Trichoderma harzianum rifai strain uygulamasının farklı çevresel stres koşullarında tatlı mısır üretiminde bitki çıkışı ve gelişimini inceledikleri çalışmalarında, Trichoderma uygulamasının çimlenmeyi ve bitki gelişimini kontrol grubuna göre artırdığını ve bu bitkilerin çevresel streslerden daha az etkilendiklerini bildirmişlerdir. Domates ve kanola bitkilerinde Trichoderma'nın ürettiği sekonder metobolitleri ve etkilerini inceleyen bir çalışmada bu metabolitlerin bitkide oksin gibi işlevler gördüğü ve tohum çimlenme gücünü uygulanmayanlara göre arttırdığ 1 bildirilmiştir (Vinale et al., 2008). Nezarat and Gholami (2009), farklı bakterilerin mısır bitkisinin tohum çimlenmesi, bitki gelişimi ve verimi üzerine etkilerini inceledikleri çalışmalarında bakteri aşılamasının tohum çimlenme oranını aşılama yapılmayan kontrol tohumlarına göre \% 18 civarında arttırdı ğını, bu konuda bakteri türünün önemli olduğunu bildirmiştir. Araştırıcılar bu çimlenme artışının sebebi olarak tohumda nişastanın hidrolizi ve asimilasyonu için gerekli enzimlerin homonal tetikleyicisi olan giberellinin bakteri uygulamalarında daha yüksek 
sentezlenmesini göstermişlerdir. Bakonyi et al. (2013) misırın çimlenmesi üzerine Bacillus megaterium var. Phosphaticum ve Azotobacter chroococcum içeren biyolojik gübre uygulamasının etkilerini inceledikleri çalışmalarında iki farklı dozda $1 \mathrm{ml}^{-1}$ ve $3.5 \mathrm{ml} \mathrm{l}^{-1}$ uygulama yapmışlardır. Biyolojik gübre uygulaması kontrole göre \%20 oranında çimlenme yüzdesini artırmış, bu artışın biyolojik gübre uygulaması yapılmış tohumlardaki oksin gibi hormonların artışından kaynaklandığı belirtilmiştir.

Biyolojik gübre uygulaması tatlı misırda bitki gelişimini olumlu yönde etkilemiştir. Bitki boyu ve gövde çapı, tüm biyolojik gübre dozlarının uygulanması ile kontrole göre artmıştır. En uzun bitki boyu ve gövde çap1 $8 \mathrm{ml} \mathrm{kg}^{-1}$ tohum biyolojik gübre uygulamasinda $174 \mathrm{~cm}$ ve $3.46 \mathrm{~mm}$ olarak saptanmıştır. Farklı bitkilerde tek başına mikoriza, Trichoderma spp. ve Bacillus spp. ile yapılan çalışmalarda bitki gelişiminin olumlu etkilendiğine yönelik sonuçlar vardır (Çakmakçı, 2005; Demir vd., 2009; Martinez-Medina et al., 2009; Adesemoye and Egamberdieva, 2013; Taş, 2014). Araştırmacılar bu sonucu biyolojik gübrenin diğer zararlı patojenlerin kökte gelişimini azaltması, daha fazla su ve besin maddesi alınımı ve sekonder metabolitlerin olumlu etkisine bağlamışlardır.

Bitki başına koçan adedi bakımından uygulamaların etkisi istatistiki açıdan önemsiz çıksa da biyolojik gübre uygulamalarındaki koçan adedi daha yüksek bulunmuştur. Bitki başına en düşük koçan adedi 1.08 adetle biyolojik gübre uygulanmayan kontrol grubu bitkilerinde izlenirken, en yüksek koçan adedi 1.22 ile $4 \mathrm{ml} \mathrm{kg}^{-1}$ tohum biyolojik gübre uygulamasında izlenmiştir. Kavuzlu koçan ağırlıkları değerlendirildiğinde en yüksek ortalama koçan ağırlığı değeri $354.26 \mathrm{~g}$ ile $4 \mathrm{ml} \mathrm{kg}^{-1}$ tohum biyolojik gübre uygulamasında saptanmış, bunu sirasi ile $349.91 \mathrm{~g}$ ile $8 \mathrm{ml} \mathrm{kg}^{-1}$ tohum ve 322.03 $\mathrm{g}$ ile $2 \mathrm{ml} \mathrm{kg}^{-1}$ tohum biyolojik gübre uygulamaları izlemiştir. Kontrol uygulamasına göre $4 \mathrm{ml} \mathrm{kg}^{-1}$ tohum biyolojik gübre uygulaması kavuzlu koçan ağırlığını \% 13.24 oranında artırmıştır. Kavuzsuz koçan ağırlığ biyolojik gübre uygulamaları aynı istatistiki gruplandırmada yer almışlar ve sırasıyla $277.91 \mathrm{~g}$ ve $279.86 \mathrm{~g}$ ortalama ağırlık değerleri elde edilmiştir. Araştırmamızda verim değerleri $1854-2437 \mathrm{~kg} \mathrm{da}^{-1}$ arasında değişmiştir. Biyolojik gübre uygulaması verim değerini kontrol uygulamasına göre artırmıştır. Biyolojik gübre uygulamasının dozları arasında istatistiki farklılık izlenmiştir. $4 \mathrm{ml} / \mathrm{kg}$ ile $8 \mathrm{ml} / \mathrm{kg}$ tohum uygulaması aynı gruplandırmada yer alırken, 2 $\mathrm{ml} / \mathrm{kg}$ tohum uygulamasından ayrışmışlardır. En yüksek verim değeri $8 \mathrm{ml} / \mathrm{kg}$ tohum uygulamasında saptanmış, kontrol uygulamasına göre \%31.51 oranında verim artışı saptanmıştır (Çizelge 2). Tarla koşullarında 3 farklı mikoriza türünün (Glomus mosseae, G. etunicatum ve $G$. intraradices) misir bitkisinin gelişimi ve verim sonuçları üzerine etkisini inceleyen bir çalışmada tüm uygulamalar kontrole göre gelişimi ve verimi olumlu yönde etkilemiş ve en iyi değerler $G$. mosseae uygulamasında izlenmiş, mikoriza uygulanmayan kontrol uygulamasına göre \% 26.22 oranında bir verim artışı saptanmıştır (Samarbakhsh et al., 2009). Tchameni et al. (2011), yaptıkları çalışmalarında iki farklı mikoriza türü (Gigaspora margarita ve Acaulospora tuberculata) ile Trichoderma asperellum'u birlikte Phytophthora megakarya'ya karşı kakao bitkisinde kullanmışlardır. Mikoriza ve Trichoderma aşılaması tek başına ve beraber bitki gelişimi ve verim değerlerini aşılanmayanlara göre olumlu yönde etkilediğini bildirmişlerdir. Trichoderma (Ozbay and Newman, 2004), Mikoriza (Talaat and Shawky, 2011) ve kök bakterilerinin (Altın ve Bora, 2005; Öztekin vd., 2015) tek başlarına bitki gelişimi ve verim değerlerini iyileştirdiğini bildiren çalışmalar vardır. Toro (1997) Phytophthora megakarya bakteri ve mikoriza mantarları arasında sinerjistik etkileşimler olduğu ve bunun sonucu olarak bitki büyümesinin olumlu yönde etkilendiğini bildirmişlerdir. Yaptıkları çalışmada Bacillus subtilis ile $G$. intraradices arasında etkileşim ile fungusun kök kolonizasyon oranını ve toprakta fosfat çözünürlügüünün artığını bildirmişlerdir. Artursson et al. (2005) bakteriler ile mantarlara arasındaki yakın hücre teması ve besin maddesi- karbon değişimi gibi metabolik aktivitelerin, bitki gelişimini olumlu yönde arttırdığını bildirmektedirler. 
Çizelge. 2. Bitki gelişim özellikleri ve verime ilişkin sonuçlar

\begin{tabular}{|c|c|c|c|c|c|c|c|}
\hline Uygulamalar & $\begin{array}{c}\text { Çimlenme } \\
\text { yüzdesi (\%) }\end{array}$ & $\begin{array}{c}\text { Bitki } \\
\text { uzunluğu } \\
(\mathbf{c m})\end{array}$ & $\begin{array}{l}\text { Bitki } \\
\text { çapı } \\
(\mathrm{cm})\end{array}$ & $\begin{array}{l}\text { Bitkide } \\
\text { başına } \\
\text { Koçan } \\
\text { adedi }\end{array}$ & $\begin{array}{l}\text { Kavuzlu } \\
\text { Koçan } \\
\text { ağırlığı } \\
\text { (gram) }\end{array}$ & $\begin{array}{l}\text { Kavuzsuz } \\
\text { Koçan } \\
\text { ağırlığı } \\
\text { (gram) }\end{array}$ & $\begin{array}{r}\text { Verim } \\
\text { (kg/da) }\end{array}$ \\
\hline $2 \mathrm{ml} / \mathrm{kg}$ tohum & $87.9 \mathrm{a}$ & $166.7 \mathrm{a}$ & $3.29 \mathrm{a}$ & 1.19 & $322.03 \mathrm{~b}$ & $254.13 \mathrm{~b}$ & $2157 \mathrm{ba}$ \\
\hline $4 \mathrm{ml} / \mathrm{kg}$ tohum & $91.1 \mathrm{a}$ & $172.6 \mathrm{a}$ & $3.39 \mathrm{a}$ & 1.22 & $354.26 \mathrm{a}$ & $277.91 \mathrm{a}$ & $2381 \mathrm{a}$ \\
\hline $8 \mathrm{ml} / \mathrm{kg}$ tohum & $90.5 \mathrm{a}$ & $174.0 \mathrm{a}$ & $3.46 \mathrm{a}$ & 1.20 & $349.91 \mathrm{a}$ & $279.86 \mathrm{a}$ & $2437 \mathrm{a}$ \\
\hline Kontrol & $80.6 \mathrm{~b}$ & $150.1 \mathrm{~b}$ & $2.88 \mathrm{~b}$ & 1.08 & $312.85 \mathrm{~b}$ & $240.33 \mathrm{~b}$ & $1853 \mathrm{c}$ \\
\hline LSD & $4.29 * *$ & $16.20 *$ & $0.26^{*}$ & Ö.D & $26.3 * *$ & $21.56 * *$ & $175.1 * *$ \\
\hline
\end{tabular}

*: \%5 seviyesinde önemlidir. **: \%1 seviyesinde önemlidir Ö.D. :önemli değil

Çizelge 3'de koçan kalite özellikleri ile alakalı parametreler verilmiştir. Koçan uzunluğu koçan çap1 üzerine uygulamaların etkisi istatistiki olarak saptanmasa da, biyolojik gübre uygulamaları kontrole göre daha uzun ve daha çaplı koçan oluşturmuştur. En düşük değerler her iki parametrede de hiçbir uygulama yapılmayan kontrol uygulamasındadır. Koçanda bulunan sıra sayıları biyolojik gübre uygulamaları bakımından önemli bulunmuştur. Koçanlarda bulunan sıra sayıları 14.50 ile 16.78 arasında yer almıştır. Biyolojik gübre uygulamasının tüm dozları aynı istatistiki grupta yer almış ve kontrol uygulamasına göre sıra sayılarını arttırmıştır. Koçanda bir sırada bulunan dane sayıları arasındaki fark istatistiki olarak önemlidir. En düşük dane sayısı 36.29 adetle kontrol grubu bitkilerinden elde edilmiştir. En yüksek adet ise 40.12 ile $8 \mathrm{ml} / \mathrm{kg}$ tohum dozu uygulamasında izlenmiştir. Tüm biyolojik gübre dozları arasında istatistiki fark gözlenmemiştir. Uygulamalar toplam suda çözünür kuru madde oranını istatistiki olarak etkilememişlerdir. TSÇKM değeri 14.19 ila 15.34 arasında saptanmıştır. Toprakta serbest yaşayan fosfat çözücü bakteriler, organik ve inorganik fosfor bileşenlerinden fosforu serbest hale geçirirler (Kucey et al., 1989) ve bu artan serbest fosforu mikoriza hifleri kolaylıkla bitkiye aktarabilir, bu da meyve gelişimini olumlu yönde etkiler (Smith and Read, 2008). Birçok bitkide farklı çalışmalar fosfat çözücü bakteriler ile mikorizaların sinerjik etkileşimlerini bildirmiş, bu etkileşim sonucu alınan yeterli besin maddesinin bitki gelişimini ve meyve kalitesini olumlu yönde etkilediğini belirtmişlerdir (Barea et al., 1997; Kim et al., 1998).

Çizelge. 3. Koçan kalite özelliklerine ilişkin sonuçlar

\begin{tabular}{|c|c|c|c|c|c|}
\hline Uygulamalar & $\begin{array}{l}\text { Koçan } \\
\text { uzunluğu } \\
\text { (cm) } \\
\end{array}$ & $\begin{array}{l}\text { Koçan çapı } \\
(\mathrm{mm})\end{array}$ & $\begin{array}{l}\text { Sira Sayısı } \\
\text { (adet) }\end{array}$ & $\begin{array}{l}\text { Sirada dane } \\
\text { sayısı } \\
\text { (adet) } \\
\end{array}$ & $\begin{array}{l}\text { TSÇKM } \\
(\%)\end{array}$ \\
\hline $2 \mathrm{ml} / \mathrm{kg}$ tohum & 20.30 & 4.33 & $16.33 \mathrm{a}$ & $38.37 \mathrm{ab}$ & 15.34 \\
\hline $4 \mathrm{ml} / \mathrm{kg}$ tohum & 20.61 & 4.39 & $16.78 \mathrm{a}$ & $39.66 \mathrm{a}$ & 15.32 \\
\hline $8 \mathrm{ml} / \mathrm{kg}$ tohum & 20.78 & 4.38 & $16.66 \mathrm{a}$ & $40.12 \mathrm{a}$ & 15.23 \\
\hline Kontrol & 19.23 & 4.24 & $14.50 \mathrm{~b}$ & $36.29 \mathrm{~b}$ & 14.19 \\
\hline LSD & Ö.D. & Ö.D. & 1.41 & 3.29 & Ö.D. \\
\hline
\end{tabular}

*: \%5 seviyesinde önemlidir, **: \%1 seviyesinde önemlidir, Ö.D: önemli değil

Mikorizanin kök kolanizasyonuna bakıldığında doz artışına bağlı olarak mikoriza kolonizasyonunda artış saptanmıştır. (Çizelge 4). Toth et al. (1984) mısır bitkisinde yaptıkları çalışmalarında köklerdeki mikoriza kolonizasyonu ile yaprakların fosfor içerikleri arasında bir ilişki olup olmadığın araştırmışlar ve artan kolonizasyonun daha fazla fosfor birikimine neden olduğunu bildirmişlerdir.
Çizelge. 4. Uygulamaların kök mikoriza kolonizasyonu üzerine etkisi

\begin{tabular}{|c|c|}
\hline Uygulamalar & Kök Kolanizasyonu (\%) \\
\hline $2 \mathrm{ml} / \mathrm{kg}$ tohum & $39.93 \mathrm{c}$ \\
\hline $4 \mathrm{ml} / \mathrm{kg}$ tohum & $50.71 \mathrm{~b}$ \\
\hline $8 \mathrm{ml} / \mathrm{kg}$ tohum & $58.78 \mathrm{a}$ \\
\hline Kontrol & $3.23 \mathrm{~d}$ \\
\hline LSD & $4.22 * *$ \\
\hline
\end{tabular}


Domatesde yapılan bir çalışmada farklı dozlarda Glomus fasciculatum uygulanmış, doz artışı ile kök kolonizasyonu artmıştır ve artan hif oranı ile su ve besin maddelerinin alınımının arttığı, bunun sonucunda da verim ve bazı kalite özelliklerinin iyileştiği görülmüştür (Öztekin ve Ece, 2014).

\section{SONUÇ}

Hastalık ve zararlılar ile mücadelede, toprak verimliliği ve sürdürülebilirliğinin devamında, kimyasal gübrelerin çevreye olumsuz etkilerini azaltmak için son yıllarda kullanımı yaygınlaşan ve farklı bileşimler şeklinde de uygulamaları başlayan mikrobiyal gübrelerin tarımda önemi artmaktadır. Bitki gelişimini teşvik edici özellikleri bulunan ve biyolojik kontrol ajanı olan mikroorganizmaların etkileri, kompleks bir süreç olup, mikroorganizma türü ve sayısı, bitki tipi, toprak özellikleri, çevresel faktörlere bağlı olarak değişebilmektedir. Çalışmamızda tatlı mısır üretiminde Endomycorrhiza, Trichoderma spp, Bacillus subtilis ve $B$. megaterium içerikli biyolojik gübre karışımın etkinliği tatlı mısır üretiminde test edilmiş olup, çimlenme, bitki gelişimi, verim artışı ve meyve kalitesi üzerine etkili olduğu, birçok ölçülen parametrede 4 ve $8 \mathrm{ml} / \mathrm{kg}$ tohum uygulamalarının birbirine yakın değerler verip, aynı istatistiki gruplandırmada yer aldığ $1, \quad 4 \quad \mathrm{ml} / \mathrm{kg}$ tohum uygulamasının uygulama dozu olarak ekonomik olacağı sonucuna varılmıştır.

\section{TESEKKÜR}

Araştırmanın yürütülmesinde sağladığı katkılar nedeniyle Koppert Biyolojik Mücadele ve Polinasyon Sistemleri Sanayi ve Ticaret Ltd. Şirketine teşekkürlerimizi sunarız.

\section{KAYNAKLAR}

Adesemoye, A.O., Egamberdieva, D., 2013. Beneficial Effects of Plant Growth- Promoting Rhizobacteria on Improved Crop Production: Prospects for Developing Economies. Bacteria in Agrobiology: Crop Productivity, D.K. Maheshwari et al. (eds.), Springer-Verlag Berlin Heidelberg, 45-63.

Adesemoye, A.O., Obini, M., Ugoji, E.O., 2008. Comparison of plant growth promotion with Pseudomonas aeruginosa and Bacillus subtilis in three vegetables. Brazilian J. Microbiol., 39:423-426.

Altın, N., Bora, T., 2005. Bitki gelişimini uyaran kök bakterilerinin genel özellikleri ve etkileri. Anadolu Ege Tarımsal Araştırma Enstitüsü Derğisi 15(2): 87-103.
Anonim, 2016. Fao internet sitesi http://faostat.fao.org/faostat (Erişim tarihi: 12.06.2017).

Antoun H., Kloepper J.W., 2001. Plant growth promoting rhizobacteria. In: Brenner S, Miller $\mathrm{JH}, \quad$ editors. Encyclopedia of Genetics. Academic; New York: 2001. pp. 1477-1480.

Antoun, H., Prevost, D., 2005. Ecology of plant growth promoting rhizobacteria. In: PGPR: Biocontrol and Biofertilization, Siddiqui, Z.A. (Ed.), Dordrecht, Germany: Springer, pp. 1-38.

Artursson, V., Finlay, R.D., Jansson, J.K., 2005. Interactions between arbuscular mycorrhizal fungi and bacteria and their potential for stimulating plant growth. Environmental Microbiology, 8(1), 1-10.

Bakonyi, N., Bott, S., Gajdos, E., Szabo, A., Jakab, A., Toth, A., Makleit, P., Veres, S.Z., 2013. Using Biofertilizer to Improve Seed Germination and Early Development of Maize. Pol. J. Environ. Stud. 22(6), 1595-1599.

Barea, J.M., Azcón-Aguilar, C., Azcón, R., 1997. Interactions between mycorrhizal fungi and rhizosphere microorganisms within the context of sustainable soil-plant systems. In Multitrophic Interactions in Terrestrial Systems. Gange, A.C., Brown, V.K. (eds). Oxford, UK: Blackwell Science, pp. 65-77.

Benitez, T., Rincon, A. M., Limon, M.C., Codon, A.C., 2004. Biocontrol mechanisms of Trichoderma strains. Int. Microbiol., 7, 249260.

Björkman, T., Blanchard, L.M., Harman, E.G., 1998. Growth Enhancement of Shrunken-2 Sweet Corn by Trichoderma harzianum 1295-22: Effect of Environmental Stress. J. Amer. Soc. Hort. Sci. 123. (1): 35-40.

Bora T., Özaktan, H., Yıldız, M., 1995. Siderefor üreten bakterilerle bazı kültür bitkilerinde fusarium solgunluklarının önlenmesi üzerine araştırmalar. TÜBİTAK-TOAG-1074 No'lu Proje Sonuç Raporu, $28 \mathrm{~s}$.

Çakmakçı, R., 2005. Bitki Gelişimini Teşvik Eden Rizobakterilerin Tarımda Kullanımı. Atatürk Üniv. Zir.Fak.Derg., (1), 97-107.

Demir, S., Şensoy, S., Ocak, E., Tüfenkçi, Ş., Demir Durak, E., Erdinç, Ç., Ünsal, H., 2009. Effects of arbuscular mycorrhizal fungus, humic acid, and whey on wilt disease caused by Verticillium dahliae Kleb. in three solanaceous crops. Turkish Journal of Agriculture and Forestry. 39, 300-309. 
El-Katatny, M. H., Idres, M. M., 2014. Effects of single and combined inoculations with Azospirillum brasilense and Trichoderma harzianum on seedling growth or yield parameters of wheat (Triticum vulgaris L., Giza 168) and corn (Zea mays L., hybrid 310). Journal of plant nutrition, 37(12), 19131936.

Erbach, D.C., 1982. Tillage for continous corn and soybean rotation. Transactionsvof the ASAE. 25(4): 906-931.

Garcia, L.J.A., Probanza, A., Ramos, B., Manero, F.J.G., 2003. Effects of three plant growthpromoting rhizobacteris on the growth of transplants of tomato and pepper in two different sterilized and nonsterilized peats. Arch. Agro. and Soil Sci., 49: 119-127.

Giovannetti M., Mosse, B., 1980. An evaluation of techniques for measuring vesicular arbuscular mycorrhizal infection in roots. New Phytologist, 84, 489-500.

Glick, B.R., 1995. The enhancement of plant growth by free-living bacteria, Can. J. Microbiol., 41: 109-117

Güneş A, Ataoğlu, N., Turan, M., Eşitken, A., Ketterings, Q.M., 2009. Effects of phosphatesolubilizing microorganisms on strawberry yield and nutrient concentrations. J. Plant Nutr. Soil Sci., 173: 385-392.

Güneş, A., Turan, M., Güllüce, M., Şahin, F., Karaman, M.R., 2013. Farklı bakteri uygulamalarının kaya fosfatının çözünürlüğü üzerine etkisi. Toprak Su Dergisi, 2(1).

Harman, G.E., 2000. Myths and dogmas of biocontrol: Changes in perceptions derived from research on $T$. harzianum T-22. Plant Diseases, 84: 377-393.

Jeon, J.S., Lee, S.S., Kim, H.Y., Ahn T.S., Song, H.G., 2003. Plant growth promotion in soil by some inoculated microorganisms. J. Microbial., 41: 271-276.

Kim, K.Y., Jordan D., McDonald, G.A., 1998. Effect of phosphate-solubilizing bacteria and vesicular-arbuscular mycorrhizae on tomato growth and soil microbial activity. Biol Fert Soils., 26:79-87.

Kleifeld, O., Chet, I., 1992. Trichoderma harzianum interaction with plants on effect on growth response. Plant Soil, 144: 267-272.

Kucey, R.M.N., Janzen, H.H., Leggett, M.E., 1989. Microbiologically mediated increases in plantavailable phosphorus. In Advances in Agronomy. Brady, N.C. (eds.). New York, USA: Academic Press, pp. 199-228.
Küçük, Ç., Güler,.İ., 2009. Bitki Gelişimini Teşvik Eden Bazı Biyokontrol Mikroorganizmalar Elektronik Mikrobiyoloji Dergisi TR (Eski adı: OrLab On-Line Mikrobiyoloji Dergisi), 7 (1): 30-42.

Martinez-Medina, A., Pascual, J. A., Lioret E., Roldan, A., 2009. Interactions between arbuscularmycorrhizal fungi and Trichoderma harzianum and their effects on Fusarium wilt in melon plants grown in seedling nurseries. J Sci Food Agric., 89: 1843-1850.

Meyer S.L.F., Roberts, D.P., 2002. Combinations of biocontrol agents for management of plantparasitic nematodes and soilborne plantpathogenic fungi. J. Nematol., 34: 1-8

Misra, M., Kumar, U., Misra, P.K., Prakash, V., 2010. Efficiency of plant growth promoting rhizobacteria for the enhancement of Cicer arietinum L. growth and germination under salinity. Advances in Biological Research, 4(2): 92-96.

Nezarat, S., Gholami, A., 2009. Screening Plant Growth Promating Rhizobacteria for Improving Seed Germination, seedling Growth and Yield of Maize. Pakistan Journal of Biological sciences 12(1): 26-32.

Ortaş, İ., 2000. Mikorizanın Çevre Bilimlerinde Kullanımı ve Önemi. GAP Çevre Kongresi, 1618 Ekim 2000, Şanlıurfa, s: 255-264.

Ortaş, İ., Ergün, B., Ortakçı, D., Ercan, S., Köse, Ö., 1999. Mikoriza Sporlarının Üretilmesi ve Tarımda Kullanım Olanaklarının İrdelenmesi. Doğa Dergisi, Sayı 4: 959-968

Ozbay, N., Newman, S.E., 2004. Biological control with Trichoderma spp with emphasis on $T$. harzianum. Pakistan Journal of Biological Science, 7(4): 478-484.

Öztekin G.B., Tüzel, Y., Mehmet, E.C.E., 2015. Potasyum Çözücü Bakteri Aşılamasının sera Domates Yetiştiriciliğinde Bitki Gelişimi, Verim ve Meyve Kalitesi Üzerine etkileri. Türkiye Tarımsal Araştırmalar Dergisi, 3(1): 41-47.

Öztekin, G. B., Ece, M., 2014. Sera Domates Yetiştiriciliğinde Symbion VAM (Glomus fasciculatum) İnokulasyonunun Bitki Gelişimi, Verim ve Meyve Kalitesi Üzerine Etkisinin Belirlenmesi. Türkiye Tarımsal Araştırmalar Dergisi, 1(1), 35-42.

Ram, R.L., Maji, C., Bindroo, B.B., 2013. Role of PGPR in different crops-an overview. Indian J. Seric, 52(1): 1-13.

Raupach G.S, Kloepper, J. W., 1998. Mixtures of plant growth-promoting rhizobacteria enhance biological control of multiple cucumber pathogens. Phytopathol., 88: 1158-1164. 
Samarbakhsh, S., Rejali, F., Ardakani, M.R., Nejad, F.P., Miransari, M., 2009. The combined effects of fungicides and arbuscular mycorrhiza on corn (Zea mays L.) growth and yield under field conditions. Journal of Biological Sciences, 9 (4): 372-376.

Smith, S., Read, D. J., 1997. Mycorrhizal Symbiosis. Second Edition. Academic Press. London

Smith, S., Read, D.J., 2008. Mycorrhizal Symbiosis. Academic Press, San Diego, CA.

Srivastava, R., Khalid, A., Singh, U.S., Sharma, A.K., 2010. Evaluation of arbuscular mycorrhizal fungus, fluorescent Pseudomonas and Trichoderma harzianum formulation against Fusarium oxysporum $f$. sp. lycopersici for the management of tomato wilt. Biological control, 53(1), 24-31

Talaat N.B., Shawky, B.T., 2011. Influence of arbuscular mycorrhizae on yield, nutrients, organic solutes and antioxidant enzymes of two wheat cultivars under salt stress. Journal of Plant Nutrition and Soil Science, 174(2): 283291.

Taş, B., 2014. Effect of the Mycorrhiza Application on the Agronomical Properties of Sweet Corn Varieties. Journal of Agriculture and Allied Sciences, 3(2): 41-47.

Tchameni, S. N., Ngonkeu, M.E.L., Begoude, B.A.D., Nana, L.W., Fokom, R., Owona, A.D., Kuaté, J., 2011. Effect of Trichoderma asperellum and arbuscular mycorrhizal fungi on cacao growth and resistance against black pod disease. Crop protection, 30(10), 1321-1327.
Toro, M., Azcón, R., Barea, J.M., 1997. Improvement of arbuscular mycorrhiza development by inoculation of soil with phosphate-solubilizing rhizobacteria to improve rock phosphate bioavailability (32P) and nutrient cycling. Appl Environ Microbiol, 63: 4408-4412.

Toth, R., Page, T., Castleberry, R., 1984. Differences in mycorrhizal colonization of maize selections for high and low ear leaf phosphorus. Crop Science, 24(5), 994-996.

Turgut, İ., 2000. Bursa Koşullarında Yetiştirilen Şeker Mısırında (Zea mays saccharata Sturt.) Bitki Sıklığının ve Azot Dozlarının Taze Koçan Verimi ile Verim Öğeleri Üzerine Etkileri. Turk. J. Agric. For., 24: 341-347.

Vazquez, M. M., César, S., Azcón R., Barea, J.M., 2000. Interactions between arbuscular mycorrhizal fungi and other microbial inoculants (Azospirillum, Pseudomonas, Trichoderma) and their effects on microbial population and enzyme activities in the rhizosphere of $\mathrm{m}$ ize plants. Applied Soil Ecology, 15(3): 261-272.

Vinale F., Sivasithamparam, K., Ghisalberti, E.L., Marra, R., Barbetti, M.J., Li, H., Woo, S.L., Lorito, M., 2008. A novel role for Trichoderma secondary metabolites in the interactions with plants. Physiol Mol Plant Pathol, 72: 80-86.

Whipps, J. M., 2001. Microbial interactions and biocontrol in the rhizosphere. Journal of Experimental Botany, 52: 487-411. 